\title{
Studied on Effect of Non - genetic Factors on Reproduction Traits in Holstein Friesian x Deoni Cows
}

\author{
S.S. Bhutkar ${ }^{1}$, B. M. Thombre ${ }^{2}$ and D.V. Bainwad ${ }^{3}$ \\ Department of Animal Husbandry and Dairy Science, College of Agriculture, Vasantrao Naik Marathwada \\ Krishi Vidyapeeth, Parbhani 431402 (MS) India
}

\begin{abstract}
The research was conducted to evaluate the effect of non - genetic factors on reproduction traits in Holstein Friesian x Deoni cattle. Data representing 287 Holstein Friesian x Deoni cows from 1177 total records of lactation over a 30 years period were analysed to determine the effect of age at first calving, season of calving and period of calving on reproduction traits. The overall least squares means of age at first calving, service period, gestation period and inter calving period were $1414.78 \pm 8.73,158.70 \pm 4.10,274.93 \pm 0.70$ and $431.74 \pm 4.25$, days respectively. The age at first calving were significant effect on service period, gestation period and non significant effect on inter calving period. All sources of variation for season of calving on reproduction traits were non significant. The period of calving had significant effect on age at first calving, service period, gestation period, whereas non significantly affected on inter calving period.
\end{abstract}

Keyword: CCBP, Holdeo Genetic factors, Reproduction, Traits,

\section{Introduction}

The improvement in indigenous cattle breeds for milk production through selection has not been effective up to the desired levels. Considering the large needs and the rapid development in milk production, crossbreeding of local cattle with exotic dairy breeds was therefore thought to be the only option. The impact of crossbreeding was improved milk production, per capita availability of milk, growth rate and reproductive efficiency in terms of age at first calving, service period, gestation period and inter calving period.

Thus, crossbreeding of indigenous breed with exotic breeds of high genetic potential is considered to be a rapid and effective method of improvement. Vasantrao Naik Marathwada Krishi Vidyapeeth, Parbhani has taken a project Cattle Cross Breeding Project for improvement of Deoni cattle breed by cross breeding with Holstein Friesian. The present study was therefore, planned to assess the effect of non genetic factors on reproduction traits in HF X Deoni crossbred cows.

\subsection{Study area}

\section{Materials And Methods}

This study was conducted at Cattle Cross Breeding Project (CCBP ) in Vasantrao Naik Marathwada Krishi Vidyapeeth, Parbhani (MS). The CCBP is situated between $17^{\circ} 35^{\prime} \mathrm{N}$ and $20^{\circ} 40^{\circ} \mathrm{N}$ latitude and between $70^{\circ} 40^{\prime} \mathrm{N}$ and $78^{\circ} 15^{\circ} \mathrm{E}$ longitude. The mean daily maximum temperature varies from $29.1^{\circ} \mathrm{C}$ in December to $42.5^{\circ} \mathrm{C}$ in May. The mean daily minimum temperature varies from $6.9^{\circ} \mathrm{C}$ in December to $25.4^{0} \mathrm{C}$ in May. The relative humidity ranges from 11 to $90 \%$. Normally the summer becomes hot and general dryness persists throught the year except during south-west monsoon. The region is essentially a subtropical one and it comes under assured rainfall zones with an average rainfall of $900 \mathrm{~mm}$ spread in about 70 rainy days mostly received from June to September.

\subsection{Management of animals}

The management and feeding practices followed on CCBP research farm is uniform. Deoni receive their ration according to the feeding schedule. After commencement of rainy season within a month grazing is available and grazing practices are followed from mid of July to end of January, in addition to grazing regular feeding of dry and green is practiced. At the time of morning and evening milking concentrates are allowed to each individual cow in accordance of their requirement for maintenance plus production. Dry roughages of sorghum and the green as per availability (Green maize, Lucerne, Green Sorghum, Natural grasses) are fed to them. Good housing facilities exist at the farm. Enough health cover is provided to protect the animals from epidemics and causal incidences of ill- health and eventualities.

\subsection{Sources and nature of data}

Data representing 287 HF X Deoni cows from CCBP with 1177 total records of lactation over a 30 years period ( 1981 to 2010 ) were collected and organized to study the effect of age at first calving, season of calving and period of calving on production traits. The complete years were divided into 4 seasons and 6 periods 
having 5 years each. Five levels of age at first calving (AFC) were coded as $A_{1}<1200$ days to $A_{6}<1600$ days with class interval 150 days. The four seasons namely winter ( December to February), summer ( March to May), monsoon (June to September ) and post monsoon (October to November) were codeded as $S_{1}, S_{2}, S_{3}$ and $\mathrm{S}_{4}$. Each cow having at least theree offsprings was considered in this study.

\subsection{Statistical analysis}

Data were analysed by linear model (SAS, 2002). When the analysis of variance indicated the existance of significant within class, Duncan Multiple Range Test (DMRT) Kramar (1957) were emplyoed to test and locate means that are significantly differed from the rest.

The following statistical model was employed to analyse the data.

$\mathrm{Y}_{\mathrm{ijk}}=\mu+\mathrm{S}_{\mathrm{i}}+\mathrm{P}_{\mathrm{j}}+\mathrm{e}_{\mathrm{ijk}}$

Where,

$$
\mathrm{Y}_{\mathrm{ijk}}=\text { is the record of a cow calved during } \mathrm{j}^{\text {th }} \text { period in } \mathrm{i}^{\text {th }} \text { season }
$$

$\mu=$ is the population mean common to all the observations

$\mathrm{S}_{\mathrm{i}}=$ is the effect of $\mathrm{i}^{\text {th }}$ season of calving (1..4)

$\mathrm{P}_{\mathrm{j}}=$ is the effect of $\mathrm{j}^{\text {th }}$ period of calving (1..6)

$\mathrm{e}_{\mathrm{ijk}}=$ is the random error assumed to be $\operatorname{NID}\left(0, \delta^{2}, \mathrm{e}\right)$

\subsection{Age at first calving}

\section{Results And Discussion}

Age at first calving is an important economic traits of cattle having bearing on life time production, generation interval and genetic gain. Early age at first calving may increase profit, reduce generation interval and help in enhancing genetic gain per unit time. However, too early age at first calving may be detrimental for growth, development and overall productivity of an animal. The least squares means and ANOVA of age at first calving as affected by season and period of calving are presented in Table 1 and 2, respectively. The overall LSM of AFC of Holstein Friesian x Deoni cow was $1414.78 \pm 8.73$ days. These results were similar to Patil (1983) in Holstein Friesian x Deoni crossbred, Singh and Dave (1989) Friesian x Tharparkar crossbred and Chewale (2008) in Holstein Friesian x Deoni interse crossbred.

\subsubsection{Effect of season of calving on age at first calving}

The AFC was non significantly affected by season of calving. Minimum age at first calving was occurred during summer season. Age at first calving was increased for cows born in post post monsoon season. The results revealed that Holdeo cow have expressed their efficiency in tolerating the seasonal variation. Similar results were reported by Patter and Dave (1977) in Red Dane x Red Sindhi and Friesian x Red Sindhi crossbred, Nagarcenkar and Rao (1982) in Friesian x Tharparkar, Brown Swiss x Tharparkar and Jersey x Tharparkar, Patel et al.(1989) in Jersey x Kankrej and Thombre (1991) in Holstein Friesian x Deoni halfbred.

\subsubsection{Effect of period of calving on age at first calving}

The age at first calving was affected by period of calving $(\mathrm{P}<0.01)$. The present results indicated that there is a further scope to raise the culling levels so that AFC can be further reduced. These results were supported with Kaul et al.( 1985) in Friesian x Hariana and Brown Swiss x Hariana cattle, Kakran and Joshi (1990) in Karan Swiss cattle, Nagare and Patel (1997) in Gir crossess and Thombre et al.(2002) in Holstein Friesian x Deoni crossbred.

\subsection{Service period}

Longer service period rendered a cattle uneconomic by reducing the overall milk yield per day of calving interval. The least squares means and ANOVA of service period as affected by age at first calving, season and period of calving are presented in Table 1 and 2, respectively. The overall LSM of SP of Holstein Friesian x Deoni cow was $158.70 \pm 4.10$ days. The results were close to Siddiqui (1984) in Friesian x Sahiwal halfbred, Prabhukumar et al.(1990) in Friesian x Ongole and Thombre et al.(2001) in Holstein Friesian x Deoni halfbred.

\subsubsection{Effect of age at first calving on service period}

The service period was significantly $(\mathrm{P}<0.05)$ influenced by AFC. The highest $\mathrm{SP}$ was observed from the cows that had AFC groups $A_{5}$ was significantly higher than cows born in $A_{4}, A_{3}, A_{2}$ and $A_{1}$. These results were supported with the findings of Patter and Dave (1977) in Red Dane x Red Sindhi and Friesian x Red Sindhi cattle, Nagarcenkar and Rao (1982) in Friesian x Tharparkar, Brown Swiss x Tharparkar and Jersey x Tharparkar crossbred and Thombre (1996) in Holstein Friesian x Deoni halfbred. 


\subsubsection{Effect of season of calving on service period}

The statistical analysis revealed that observed differences of SP due to season of calving were non significant. The present results revealed that the Holstein Friesian $\mathrm{x}$ Deoni genotype basically possess certain shorter SP and well adopted to the seasonal changes of the tract, as such there will not be significant deviation in the expression of this character. Similar results were reported by Patter and Dave (1977) in Red Dane x Red Sindhi and Friesian x Red Sindhi crossbred, Chaudhary et al. (1977) in Friesian x Sahiwal crossbred, Nagarcenkar and Rao (1982) in Friesian x Tharparkar, Brown Swiss x Tharparkar and Jersey x Tharparkar cattle and Komatwar et al.(2010) in Friesian x Sahiwal cattle.

\subsubsection{Effect of period of calving on service period}

The analysis of variance indicated that effect due to period of calving on SP in Holstein Friesian $\mathrm{x}$ Deoni cow was non significant (Table 2). The higher service period was observed in $\mathrm{P}_{1}$ than other periods. $\mathrm{P}_{5}$, $\mathrm{P}_{3}, \mathrm{P}_{2}, \mathrm{P}_{4}$, and $\mathrm{P}_{6}$. The results were supported with the findings of Singh and Tomar (1991) in Karan Fries cattle, Rafique et al.(2000) in Holstein Friesian x Sahiwal interse crossbred, Dubey and Singh (2005) in Sahiwal x Holstein Friesian, Sahiwal x Red Dane, Sahiwal x Jersey and Sahiwal x Rathi x Holstein Friesian crossbred cattle and Bajetha and Singh (2011) in crossbred cattle.

\subsection{Gestation period}

It is the period from the date of conception to the date of parturition. During this period, with the development of foetus, the uterus of dam undergoes great anatomical and physiological modifications. Whereas the length of gestation is essential to forecast the approximate date of calving. The overall LSM of GP of Holstein Friesian x Deoni cow was $274.93 \pm 0.70$ days. The results were similar to Mondal et al.(2005) in Jersey cross x Sahiwal crossbred cattle, Saut et al.(2007) in crossbred cattle and Rokonuzaman et al.(2009) in crossbred cattle.

\subsubsection{Effect of age at first calving on gestation period}

The gestation period was significantly $(\mathrm{P}<0.05)$ influenced by AFC. The highest GP was observed from the cows that had AFC groups $A_{4}$ followed by $A_{5}, A_{3}, A_{2}$ and $A_{1}$. These results were supported with the findings of Nahar et al.(1992) in Red Sindhi x Deshi, Sahiwal x Deshi, Jersey x Deshi and Holstein Friesian x Deshi crossbred cattle.

\subsubsection{Effect of season of calving on gestation period}

The analysis of variance indicated that effect due to season of calving on GP in Holstein Friesian $\mathrm{x}$ Deoni cow was non significant. Higher GP was observed in $S_{4}$ followed by $S_{1}, S_{2}$ and lowest in $S_{3}$. The results revealed that seasonal changes do not influence on the variation on GP in Holdeo cow. Similar results were reported by Maulik and Systrad (1974) in Jersey x Hariana crossbred cattle.

\subsubsection{Effect of period of calving on gestation period}

The gestation period was significantly $(\mathrm{P}<0.01)$ affected by period of calving. The DMRT revealed that the GP of Holstein Friesian $x$ Deoni observed in $\mathrm{P}_{6}(275.89 \pm 0.20)$ was significantly higher than $\mathrm{P}_{4}, \mathrm{P}_{5}, \mathrm{P}_{1}$, $\mathrm{P}_{3}$ and lowest in $\mathrm{P}_{2}$. The results were supported with the findings of Das et al.(1990) in Jersey cattle and Click and Tekin (2007) in Brown Swiss cattle.

\subsection{Inter calving period}

For profitable milk production and to achieve best reproductive efficiency, the dairy cattle should reproduce at fairly regular interval. The inter calving is a period between two consecutive calvings. The overall LSM of ICP of Holstein Friesian x Deoni cow was $431.74 \pm 4.25$ days. The results were close to Deshapande and Bonde (1983) in Friesian x Sahiwal cattle, Thalkari (1984) in Friesian x Deoni cattle, Dalal et al.(1991) in Brown Swiss x Hariana cattle and Thombre et al.(2002) in Holstein Friesian x Deoni halfbed.

\subsubsection{Effect of age at first calving on inter calving period}

The effect of AFC on inter calving period was significant $(\mathrm{P}<0.01)$. The highest inter calving period was observed from cows that had AFC group $A_{5}$ followed by $A_{4}, A_{3}, A_{2}$ and lowest in $A_{1}$. These results were supported with the findings of Patil (1983) in Holstein Friesian x Deoni crossbred, Siddiqui (1984) in Holstein Friesian x Sahiwal, Dalal et al.(1993) in Holstein Friesian x Hariana and Chewale (2008) in Holstein Friesian x Deoni interse crossbred cattle. 


\subsubsection{Effect of season of calving on inter calving period}

The effect of season of calving on inter calving period was non significant. The LSM for ICP ( Days) was higher in cows calved during $S_{1}$ followed by $S_{2}, S_{3}$ and lowest in $S_{4}$ The results revealed that Holstein Friesian $x$ Deoni crossbred genotype possess shorter ICP and well adopted to the season of tract as such there will not be significant deviation in the expression of character. Deshpande and Bonde (1983) in Friesian $x$ Sahiwal crossbred, Bhatnagar et al.(1986) in Karan Fries and Karan Swiss cattle, Thakur and Singh (2000) in Jersey x Hariana crossbred and Ghatcharle (2003) in Holstein Friesian x Deoni interse crossbred.

\subsubsection{Effect of period of calving on inter calving period}

The statistical analysis revealed that observed differences of ICP due to period of calving were non significant. The LSM for ICP (Days) was higher in cows calved during $\mathrm{P}_{5}$ followed by $\mathrm{P}_{1}, \mathrm{P}_{3}, \mathrm{P}_{2}, \mathrm{P}_{4}$ and lowest in $\mathrm{P}_{6}$.The results were supported with the findings of Deshpande and Ingole (1986) in Friesian x Sahiwal crossbred, Bhoite et al.(1998) in Friesian x Jersey x Gir, Jersey x Friesian x Gir and Brown Swiss x Friesian x Gir crossbred, Ghatcharle (2003) and Chewale (2008) in Holstein Friesian x Deoni interse crossbred cattle.

Table 1. Least square means and standard error for Age at first calving ( AFC), Service period (SP), Gestation period (GP), and Inter calving ( ICP) as affected by AFC groups, season of calving and period of calving in

\begin{tabular}{|c|c|c|c|c|c|}
\hline Source & Code & AFC (Days) & SP (Days) & GP (Days) & ICP ( Days) \\
\hline Overall mean & $\mu$ & $1414.78 \pm 8.73$ & $15.70 \pm 4.10$ & $274.93 \pm 0.70$ & $431.74 \pm 4.25$ \\
\hline \multirow[t]{5}{*}{ AFC groups } & $\mathrm{A}_{1}$ & - & $149.58^{\mathrm{a}} \pm 7.23$ & $274.28^{\mathrm{b}} \pm 0.12$ & $422.09 \pm 7.48$ \\
\hline & $\mathrm{A}_{2}$ & - & $154.33^{\mathrm{ab}} \pm 8.85$ & $274.69^{\mathrm{b}} \pm 0.14$ & $425.17 \pm 9.16$ \\
\hline & $\mathrm{A}_{3}$ & - & $157.48^{\mathrm{a}} \pm 6.01$ & $274.88^{\mathrm{b}} \pm 0.90$ & $432.48 \pm 6.22$ \\
\hline & $\mathrm{A}_{4}$ & - & $162.27^{\mathrm{ab}} \pm 5.94$ & $275.38^{\mathrm{a}} \pm 0.10$ & $435.50 \pm 6.14$ \\
\hline & $\mathrm{A}_{5}$ & - & $179.83^{\mathrm{b}} \pm 10.89$ & $275.20^{\mathrm{ab}} \pm 0.17$ & $456.45 \pm 11.26$ \\
\hline \multirow[t]{4}{*}{ Season of calving } & $\mathrm{S}_{1}$ & $1406.76 \pm 14.06$ & $164.78 \pm 6.38$ & $274.66 \pm 0.10$ & $440.22 \pm 6.60$ \\
\hline & $\mathrm{S}_{2}$ & $1394.00 \pm 14.54$ & $161.63 \pm 6.51$ & $274.55 \pm 0.11$ & $434.40 \pm 6.74$ \\
\hline & $\mathrm{S}_{3}$ & $1422.89 \pm 13.42$ & $157.10 \pm 6.06$ & $274.50 \pm 0.10$ & $427.48 \pm 6.28$ \\
\hline & $\mathrm{S}_{4}$ & $1437.47 \pm 16.13$ & $148.28 \pm 7.20$ & $274.80 \pm 0.12$ & $421.86 \pm 7.46$ \\
\hline \multirow[t]{6}{*}{ Period of calving } & $\mathrm{P}_{1}$ & $1387.72^{b} \pm 11.45$ & $165.60^{\mathrm{a}} \pm 5.87$ & $275.35^{\mathrm{b}} \pm 0.80$ & $433.78 \pm 6.07$ \\
\hline & $\mathrm{P}_{2}$ & $1413.43^{b} \pm 12.93$ & $156.06^{\mathrm{a}} \pm 5.89$ & $274.29^{\mathrm{b}} \pm 0.90$ & $428.44 \pm 6.09$ \\
\hline & $\mathrm{P}_{3}$ & $1435.26^{\mathrm{b}} \pm 14.52$ & $158.31^{\mathrm{ab}} \pm 6.48$ & $275.05^{\mathrm{b}} \pm 0.10$ & $430.59 \pm 6.71$ \\
\hline & $\mathrm{P}_{4}$ & $1462.36^{\mathrm{ab}} \pm 29.46$ & $143.78^{b} \pm 12.99$ & $275.64^{\mathrm{ab}} \pm 0.22$ & $419.34 \pm 13.44$ \\
\hline & $\mathrm{P}_{5}$ & $1434.21^{\mathrm{b}} \pm 24.72$ & $159.29^{a} \pm 10.77$ & $274.57^{\mathrm{b}} \pm 0.18$ & $453.80 \pm 11.14$ \\
\hline & $\mathrm{P}_{6}$ & $1495.72^{\mathrm{a}} \pm 24.42$ & $143.16^{\mathrm{ab}} \pm 12.21$ & $275.89^{\mathrm{a}} \pm 0.20$ & $410.48 \pm 12.63$ \\
\hline
\end{tabular}

Table 2. Analysis of variance for age at first calving (AFC), service period (SP), gestation period (GP) and inter calving period (ICP) on AFC groups, season of calving and period of calving in Holstein Friesian $\mathrm{x}$ Deoni

\begin{tabular}{|c|c|c|c|c|c|c|c|c|c|}
\hline \multirow[t]{2}{*}{ Sources } & \multirow[t]{2}{*}{ DF } & \multicolumn{2}{|l|}{ AFC } & \multicolumn{2}{|l|}{ SP } & \multicolumn{2}{|l|}{ GP } & \multicolumn{2}{|l|}{ ICP } \\
\hline & & $\begin{array}{l}\text { MSS } \\
(\cdot 000)\end{array}$ & $\begin{array}{l}\text { F value } \\
\text { calculated }\end{array}$ & $\begin{array}{l}\text { MSS } \\
(\cdot 000)\end{array}$ & $\begin{array}{l}\text { F value } \\
\text { calculated }\end{array}$ & $\begin{array}{l}\text { MSS } \\
(\cdot 000)\end{array}$ & $\begin{array}{l}\text { F value } \\
\text { calculated }\end{array}$ & $\begin{array}{l}\text { MSS } \\
(\cdot 000)\end{array}$ & $\begin{array}{l}\text { F value } \\
\text { calculated }\end{array}$ \\
\hline $\mathrm{AFC}$ & 4 & & & 23580.00 & $2.39^{*}$ & 9.88 & $3.70^{* * *}$ & 23510.00 & $2.23^{\mathrm{NS}}$ \\
\hline Season & 3 & 102100.00 & $1.98^{\mathrm{NS}}$ & 17660.00 & $1.79^{\mathrm{NS}}$ & 4.59 & $1.71^{\mathrm{NS}}$ & 23630.00 & $2.24^{\mathrm{NS}}$ \\
\hline Period & 5 & 1905000.00 & $36.87^{* *}$ & 27500.00 & $2.79^{*}$ & 506.60 & $189.52^{* *}$ & 21690.00 & $2.05^{\mathrm{NS}}$ \\
\hline Error & 198 & 51660.00 & & 9843.00 & & 2.67 & & 10530.00 & \\
\hline
\end{tabular}

\section{Conclusion}

This study indicates that the performance of Holdeo $\mathrm{x}$ Deoni cows for age at first calving and inter calving period is comparatively medium which needs an improvement to lowering this using overall managemental practices in dairy farm. Most of the reproductional traits concerns seasonal changes had not any affects. Therefore, additional reproduction strategies like improving enviornmental factors and managemental factors needed to improve thereproduction performance.

\section{References}

[1]. Bajetha, G and Singh, C. V, Estimates of Genetic and Phenotypic Parameters of First Lactation and Lifetime Performance Traits in Crossbred Cattle, Indian J. Dairy. Sci. 64 (6), 2011, 494-500.

[2]. Bhatnagar, K. C., Agarwal, S. B., Singh, B. and Sigh, K, The Effect of Non Genetic Factors on Production Performance Character of Crossbred Cows, Indian. J. Dairy. Sci. 39 (3), 1986, 1986-1988.

[3]. Bhoite, U. Y., Bhoite, S. U. and Thorat, B. P, Genetic Studies of Post Partum Reproductive Traits in Triple Cross Interbred Cows, Indian J. Anim. Res. 32 (1) : 1998, 65-69.

[4]. Chaudhary, A. L., Mehara, S. C and Shriram, Factors Affecting Service Period and Dry Period of Friesian x Sahiwal, Indian J. Dairy. Sci. 30 (4) : 1977, 274-278. 
[5]. Chewale, S. S, Study on Reproductive Performance of Holstein Friesian x Deoni Interse Crossbred. Mastaral diss, MAU, Parbhani, 2008.

[6]. Click, S and Tekin, M. E, Environmental Factors Affecting Milk Yield Traits of Brown SwissCows Raised of Ulhas State Farm and Phenotypic Correlations Between Milk Yield and Fertility Traits, Indian J. Anim. Sci. 77 (2),2007, 154-157.

[7]. Dalal, D. S., Arora, K. C and Rathi, S. S, Evaluation of Performance Traits in Halfbred Cattle, Indian J. Dairy. Sci. 44 (7),1991, 401-405.

[8]. Dalal, D. S., Arora, K. C. and Rathi, S. S, Effect of Period, Season, Parity and Age at First Calving on Performance Traits in Friesian x Hariana Halfbred Cows. Indian J. Anim. Sci. 61 (9), 1993, 994-995.

[9]. Das, G. C., Das, D and Aziz, A, Production and Reproduction Performance of Jersey Cows in Assam, Livestock Advisor. 15(3), 1990, 3-7.

[10]. Deshpande, K. S and Bonde, H. S, Note on First Lactation Milk Yield in Friesian x Sahiwal Crossbreds, Indian J. Anim. Sci. 53 (3),1983, 303-306.

[11]. Deshpande, K. S and Ingole, G. K, A New Method of Estimating Breeding Efiiciency in Friesian x Sahiwal Crossbreds, Indian J. Dairy. Sci. 56 (8),1986, 890-891.

[12]. Dubey, P. P and Singh, C. V, Estimates of Genetic and Phenotypic Parameters Considering First Lactation and Lifetime Performance Traits in Sahiwal and Crossbred Cattle, Indian J. Anim. Sci. 75 (11), 2005, 1289-1294.

[13]. Ghatcharle, P. L, Effect of Season of Calving on Production Traits in Interse Progeny of Holstein Friesian x Deoni. Mastaral diss, MAU, Parbhani, 2003.

[14]. Kakran, P. K and Joshi, B. K, Factors Affecting First Lactation Production and Reproduction Triats of Karan Swiss Cattle, Indian J. Anim. Sci. 60 (2), 1990, 223-227.

[15]. Kaul, G. L., Pandey, H. N. and Katpal, B. G, Studies on Age at First Calving and its Reletionship with Weight and First Lactational Milk Yield in Crossbreds, Indian J. Dairy. Sci. 38 (4) ,1985, 332-334.

[16]. Komatwar S. J., Deshpande A. D., Kulkarni M. D., Kulkarni A. P., Yadav G. B., Ulemale A. H. and Sisode M. G, Study the Production Traits in Holstein Friesian X Sahiwal Crossbreds, Indian J. Anim. Prod. Mgmt. 26 (4), 2010, 177-181

[17]. Kramar, C. Y, Extension of Multiple Range Test to Group Correlated Adjusted Mean. Biometrics. 13, 1957, 13-18.

[18]. Maulik, S. K. and Systrad, R. E, A report on Some Important Economic Traits in Jersey x Hariana Crossbreds, Indian Vet. J. 46 :1978, 965-967.

[19]. Mondal, S. C., Alam, M. M., Rashid, M. M., Ali, M. Y and Hossain, M. M, Comparative Study on Productive and Reproductive Performance of Different Dairy Genotype Reared in Bangaladesh Agriculture University Dairy Farm, Pakistan J. Nutri. 4 (4), 2005, 222-225.

[20]. Nagarcenkar, R and Rao, M. K, Performance of Tharparkar x Exotic Crosses for Productive and Reproductive Traits, Indian J. Anim. Sci. 52 (3) ,1982, 129-138.

[21]. Nagare, W. K. and Patel, A. M, The Comparative Performance of Gir Crossbreds Under Maharashtra Conditions, Indian J. Anim. Prod. Mgmt. 13 (2), 1997, 87-92.

[22]. Nahar, T. N., Islam, M. and Hasnath, M. A, A Comparative Study on the Performances of $F_{1}$ Crossbred Cows Under Rural Conditions. Asian J. Anim. Sci. 5 (3), 1992, 435-438.

[23]. Patel. J. M., Patel, A. M., Mansuri, M. N., Patel, K. S. and Dave, A. D, Performance of Jersey x Kankrej and Holstein Friesian x Kankrej $F_{1}$ Crossbreds, Indian J. Anim. Sci. 59 (8) ,1989, 986-988.

[24]. Patil, C. Y, Study on Production and Reproduction Traits of Friesian x Deoni Crossbreds, Mastaral diss, Marathwada Agriculture University, Parbhani (MS), 1983.

[25]. Patter, A. S. and Dave, P. S, A Comparision of Red Dane x Red Sindhi with Holstein Friesian x Red Sindhi Crossbred Cows, Indian J. Dairy. Sci. 30 (2), 1977, 150-151.

[26]. Prabhukumar, V., Rao, C.H., Venketramaiah, A. and Naidu, K.N, Genetic Group Differences in the Performance of the Various Crosses of Ongole with Friesian, Brown Swiss and Jersey Breed, Indian J. Dairy. Sci. 43 (1), 1990, 46-50.

[27]. Rafique, M., Chaudhary, M. Z. and Amer, M. A, Reproductive Performance of Interse Holstein Friesian x Sahiwal Crossbred, Pakistan Vet. J. 20 (3), 2000, 109-113.

[28]. Rokonuzzaman, M., Hassan, M. R., Islam, S and Sultan, S, Productive and Reproductive Performance of Crossbred and Indigenous Dairy Cows Under Smallholder Farming System, Journal Bangladesh. Agril.Univ. 7 (1), 2009, 69-72.

[29]. SAS (Statistical Analysis System), SAS Version 9.1.3, ASA Institute Inc., Cary, NC, USA, 2002.

[30]. Saut, N., Rashid, M. M and Hossain, S. M. J, A Comparative Study on Productive and Reproductive Performance of Different Crossbred and Indigenous Dairy Cows Under Small Scale Dairy Farm Condition, Journal Live. Res 2 , 2007, 53-62.

[31]. Siddiqui, M. F, Inheritance of Different Segments of Lactation and its Genetic and Phenotypic Association with Some Factors in Friesian x Sahiwal Half and $3 / 4$ Breds Crossbreds, doctoral diss, MAU, Parbhani, 1984.

[32]. Singh, N. P and Dave, S. K, Performance of Tharparkar x Holstein Friesian Interse Crossbreds in Central India, Indian J. Anim. Prod. Mgmt. 5 (1), 1989, 1-4.

[33]. Singh, R. and Tomar, S. S, Performance Characteristics of Karan Fries Cows. Indian J. Anim. Sci. 61 (2), 1991, $192-195$.

[34]. Thakur, Y. P and Singh, B. P, Performance Evalution of Jersey x Zebu Crossbreds Involving Different Indigenous Breed, Indian Vet. J. 77 (1), 2000, 85-88.

[35]. Thalkari, B. B, Optimization of Some Production and Reproduction Traits in Friesian x Deoni and Jersey x Deoni Crossbreds, Mastaral diss, MAU, Parbhani, 1984.

[36]. Thombre, B. M, Effect of Age at First Calving on Lactation Milk Yield, Lactation Period, Dry Period, Service Period, Inter Calving Period, Peak Yield and Days Required to Reach Peak Yield of Holstein Friesian x Deoni Straight Breds in First Lactation, Mastaral diss, MAU, Parbhani, 1991.

[37]. Thombre, B. M, Study on Genetic Architecture of few Economic Characters in Holstein Friesian x Deoni Halfbred, doctoral diss, MAU, Parbhani,1996.

[38]. Thombre, B. M., Mitkari, K. R., Gujar, B. V and Karanjkar, L. M, Factors Affecting Reproductive Traits in Deoni and Holstein Friesian x Deoni Halfbreds, Indian J. Anim. Res. 35 (2), 2001, 131-133.

[39]. Thombre, B. M., Mitkari, K. R and Karanjkar, L. M, Studies on Age at First Calving and Milk Yield in Deoni and Holstein Friesian x Deoni Halfbreds, Indian J. Anim Res. 36 (2), 2002, 141-143. 